\title{
Transesterification of palm cooking oil using barium-containing titanates and their sodium doped derivatives
}

\author{
K. Y. Chew ${ }^{1}$ W. L. Tan ${ }^{1}$ N. H. H. Abu Bakar' ${ }^{1}$ M. Abu Bakar ${ }^{1}$
}

Received: 23 February 2016/ Accepted: 27 October 2016/Published online: 4 November 2016

(C) The Author(s) 2016. This article is published with open access at Springerlink.com

\begin{abstract}
BaTiO}_{3}, \mathrm{Ba}_{2} \mathrm{NiTi}_{5} \mathrm{O}_{13}$ and their Na-doped analogues were successfully synthesized via sol-gel and calcination methods. The surface properties of the prepared catalysts were characterized by scanning electron microscopy and nitrogen adsorption-desorption analysis while the basicity was determined by benzoic acid titration. The catalytic activity of the Ba-based catalysts was verified in transesterification of palm cooking oil with methanol. The optimization study was conducted by varying the oil:methanol ratio, catalyst loading, reaction temperature and duration. The highest methyl ester (ME) yield was 95\% for $5 \mathrm{wt} / \mathrm{v} \% \mathrm{Na}-\mathrm{Ba}_{2} \mathrm{NiTi}_{5} \mathrm{O}_{13}$ at a methanol to oil ratio of $12: 1$ at $150{ }^{\circ} \mathrm{C}$ for $2 \mathrm{~h}$.
\end{abstract}

Keywords Transesterification $\cdot \mathrm{BaTiO}_{3} \cdot \mathrm{Ba}_{2} \mathrm{NiTi}_{5} \mathrm{O}_{13}$. Sodium-doped · Catalyst

\section{Introduction}

Biodiesel has attracted interest as a promising energy source to substitute the drastically depleted fossil fuels in recent decades [1]. The main content in biodiesel is fatty acid methyl ester (FAME), which is an environmentally friendly fuel with clean burn, easily made, biodegradable, non-toxic and free of sulfur and aromatic compounds [2]. Transesterification reaction is the most common method to convert vegetable oils or animal fat into FAMEs using methanol in the presence of suitable catalyst. Generally,

M. Abu Bakar

bmohamad@usm.my; bmohamad916@gmail.com

1 School of Chemical Sciences, Universiti Sains Malaysia, 11800 Penang, Malaysia heterogeneous catalysts are preferred over homogenous catalysts as it provides advantages such as simple separation process, good reusability and saponification prevention $[3,4]$.

Metal oxides have been extensively studied as heterogeneous base catalysts in transesterification. The presence of $\mathrm{M}^{\delta+}-\mathrm{O}^{\delta-}$ ion pairs in these oxides produces basic sites that are believed to be actively involved in the transesterification reaction [5]. Several attempts have been employed to further improve their catalytic properties and stability, such as doping [6, 7], immobilizing or supporting [8] and mixed oxide systems $[9,10]$. For example, Mukenga et al. [8] have shown that the oil conversion for $\mathrm{TiO}_{2}$ supported $\mathrm{ZnO}$ is higher than unsupported $\mathrm{ZnO}$ catalyst. Mar and Somsook [6] showed that the catalytic activity and stability of $\mathrm{CaO}$ catalyst can be enhanced by doping with $\mathrm{KCl}$. Lee et al. [9] also proved that the binary $\mathrm{MgO}-\mathrm{ZnO}$ catalyst exhibits superior physicochemical properties as compared to $\mathrm{MgO}$ or $\mathrm{ZnO}$ catalysts.

Barium oxide catalysts were reported to exhibit superior catalytic performance in transesterification. The catalytic reactivity of $\mathrm{BaO}$ is higher than $\mathrm{CaO}, \mathrm{SrO}$ and $\mathrm{MgO}$ due to its high basicity [11-16]. The catalytic properties of $\mathrm{BaO}$ supported on $\mathrm{Al}_{2} \mathrm{O}_{3}$ [17], $\mathrm{SiO}_{2}$ [18] and $\mathrm{SrO}\left(\mathrm{Al}_{2} \mathrm{O}_{3}\right)$ [19] towards the transesterification reaction have also been studied. The reactivity of the supported $\mathrm{BaO}$ catalysts can be related to its dispersion on the support, surface composition and surface properties. Thus far, the study on barium-based binary or tertiary oxides in transesterification is rarely reported. The only two recent studies were conducted by Sherstyuk et al. [20, 21]. They successfully prepared $\mathrm{Ba}-\mathrm{Al}-\mathrm{O}$ (viz. $\mathrm{BaAl}_{13.2} \mathrm{O}_{20.8}$ and $\mathrm{BaAl}_{12} \mathrm{O}_{19}$ ) and $\mathrm{Ba}-\mathrm{La}-\mathrm{O}$ (viz. $\mathrm{BaLa}_{2} \mathrm{O}_{4} / \mathrm{La}_{2} \mathrm{O}_{3}$ and $\mathrm{Ba}_{0.04} \mathrm{La}_{1.96} \mathrm{O}_{3}$ ) binary systems via precipitation and calcination method and demonstrated their application in the transesterification of 
rapeseed oil. The stability of $\mathrm{Ba}-\mathrm{Al}-\mathrm{O}$ is higher than $\mathrm{Ba}-$ $\mathrm{La}-\mathrm{O}$ binary catalysts and the conversion of rapeseed oil over $\mathrm{Ba}-\mathrm{Al}-\mathrm{O}$ can achieve $\sim 100 \%$ at optimum conditions.

Recently, we have successfully synthesized $\mathrm{BaTiO}_{3}, \mathrm{Na}-$ doped $\mathrm{BaTiO}_{3}$ [22] and $\mathrm{Ba}_{2} \mathrm{NiTi}_{5} \mathrm{O}_{13}$ [23] particles via solgel and calcination method. As the continuation of the work, herewith, we report their catalytic study in the transesterification of palm cooking oil. The Na-doped $\mathrm{Ba}_{2} \mathrm{NiTi}_{5} \mathrm{O}_{13}$ was also prepared for comparison purposes. The surface properties of un-doped and doped oxides are studied via SEM, BET and benzoic acid titration. The influence of sodium dopant on the surface properties, as well as the catalytic performance is also reported in this study.

\section{Materials and methods}

\section{Materials}

All materials were used as purchased. Titanium tetraisopropoxide $\left(\mathrm{Ti}\left(\mathrm{OPr}^{\mathrm{i}}\right)_{4}, 99.999 \%\right.$, Fluka), barium hydroxide monohydrate $\left(\mathrm{Ba}(\mathrm{OH})_{2} \cdot \mathrm{H}_{2} \mathrm{O}, \geq 98 \%\right.$, Fluka), nickel acetate tetrahydrate $\left(\mathrm{Ni}\left(\mathrm{CH}_{3} \mathrm{COO}\right)_{2} \cdot 4 \mathrm{H}_{2} \mathrm{O}, \geq 99.0 \%\right.$, Fluka $)$, sodium hydroxide $(\mathrm{NaOH}, \geq 99.99 \%$, JT Baker), sodium carbonate $\left(\mathrm{NaCO}_{3}, \geq 99.5 \%\right.$, R\&M), methanol $\left(\mathrm{CH}_{3} \mathrm{OH}\right.$; $\geq 98 \%$, R\&M Chemicals), isopropanol $\left(\left(\mathrm{CH}_{3}\right)_{2} \mathrm{CHOH}\right.$, $\geq 99.7 \%$, R\&M Chemicals), $n$-hexane $\left(\mathrm{C}_{6} \mathrm{H}_{14}, \geq 99 \%\right.$, QRëC), benzoic acid $\left(\mathrm{C}_{6} \mathrm{H}_{5} \mathrm{COOH}, \geq 99.5 \%\right.$, Sigma Aldrich) and acetic acid $\left(\mathrm{CH}_{3} \mathrm{COOH}, \geq 99.8 \%\right.$, Systerm) were analytical grade. Palm cooking oil (Delima Oil Products Sdn. Bhd) was obtained commercially.

\section{Preparation of catalysts}

In general, the catalysts were prepared via sol-gel method followed by calcination. Detailed description on the preparation of $\mathrm{BaTiO}_{3}, \mathrm{Na}$-doped $\mathrm{BaTiO}_{3}$ and $\mathrm{Ba}_{2} \mathrm{NiTi}_{5-}$ $\mathrm{O}_{13}$ has been reported elsewhere [22, 23].

\section{$\mathrm{BaTiO}_{3}$ and sodium doped $\mathrm{BaTiO}_{3}\left(\mathrm{Na}-\mathrm{BaTiO}_{3}\right)$}

As much as $399.7 \mathrm{mg}$ of $\mathrm{Ba}(\mathrm{OH})_{2} \cdot \mathrm{H}_{2} \mathrm{O}$ was dissolved in $40 \mathrm{~mL}$ of distilled water heated in an oil bath at $50{ }^{\circ} \mathrm{C}$. Then, $8 \mathrm{~mL}$ of $0.044 \mathrm{M}$ of $\mathrm{Ti}\left(\mathrm{OPr}^{\mathrm{i}}\right)_{4}$ in isopropanol (molar ratio of $\mathrm{Ba}: \mathrm{Ti}=6: 1$ ) was then added. The mixture was stirred for $2 \mathrm{~h}$ under reflux. The product (in gel form) was separated via centrifugation and washed with distilled water. The $\mathrm{BaTiO}_{3}$ catalyst was obtained by calcination of the gel at $900{ }^{\circ} \mathrm{C}$ for an hour. The $0.5 \mathrm{~mol} \%$ sodium doped derivatives was similarly prepared. However, the stipulated $\mathrm{NaCO}_{3}$ was added to $\mathrm{Ba}(\mathrm{OH})_{2} \cdot \mathrm{H}_{2} \mathrm{O}$ before the addition of
$\operatorname{Ti}\left(\mathrm{OPr}^{\mathrm{i}}\right)_{4}$. The obtained gel was then calcined at $900{ }^{\circ} \mathrm{C}$ for $5 \mathrm{~h}$.

$\mathrm{Ba}_{2} \mathrm{NiTi}_{5} \mathrm{O}_{13}$ and sodium doped $\mathrm{Ba}_{2} \mathrm{NiTi}_{5} \mathrm{O}_{13}$ (Na$\mathrm{Ba}_{2} \mathrm{NiTi}_{5} \mathrm{O}_{13}$ )

Typically, the $\mathrm{Ba}_{2} \mathrm{NiTi}_{5} \mathrm{O}_{13}$ was synthesized via two-steps. As much as $5 \times 10^{-3} \mathrm{~mol}$ of $\mathrm{Ni}\left(\mathrm{CH}_{3} \mathrm{COO}\right)_{2} \cdot 4 \mathrm{H}_{2} \mathrm{O}$ was dissolved in a mixture of isopropanol/acetic acid. Then, $1.5 \mathrm{~mL}$ of $3.33 \mathrm{M} \mathrm{Ti}\left(\mathrm{OPr}^{\mathrm{i}}\right)_{4}$ was added (at a mole ratio of $\mathrm{Ni}: \mathrm{Ti}=1: 1)$. The mixture was stirred at room temperature for $24 \mathrm{~h}$ until an olive green solution was formed. As much as $50 \mathrm{~mL}$ of distilled water was then added before subjecting to partial freeze-drying process. The obtained product (as-prepared $\mathrm{NiTiO}_{3}$ gel) was used in the subsequent step.

In a separate flask, $799.4 \mathrm{mg}$ of $\mathrm{Ba}(\mathrm{OH})_{2} \cdot \mathrm{H}_{2} \mathrm{O}$ was dissolved in $80 \mathrm{~mL}$ of distilled water and mixed with $32 \mathrm{~mL}$ of $3.0 \mathrm{M} \mathrm{NaOH}$. The whole system was heated at $50{ }^{\circ} \mathrm{C}$ while stirring to ensure the total dissolution. Then, $652.8 \mathrm{mg}$ of the as-prepared gel obtained previously was added. This was followed by the addition of $16 \mathrm{~mL}$ of $0.044 \mathrm{M} \mathrm{Ti}\left(\mathrm{OPr}^{\mathrm{i}}\right)_{4}$ in isopropanol. The mole ratio of Ba:Ni:Ti was fixed at 1:1:1.2. The mixture was stirred for another $8 \mathrm{~h}$. The product (in gel form) was separated via centrifugation and washed with distilled water. The $\mathrm{Ba}_{2}$ $\mathrm{NiTi}_{5} \mathrm{O}_{13}$ catalyst was obtained by the calcination of gel product at $900{ }^{\circ} \mathrm{C}$ for $8 \mathrm{~h}$. The sodium doped derivatives (viz. $0.5 \mathrm{~mol} \% \mathrm{Na}$ ) were similarly prepared. However, the stipulated $\mathrm{NaCO}_{3}$ was added before addition of $\operatorname{Ti}\left(\mathrm{OPr}^{\mathrm{i}}\right)_{4}$ in the second step. The obtained gel product was then calcined at $900{ }^{\circ} \mathrm{C}$ for $5 \mathrm{~h}$.

\section{Characterizations}

The surface structures and average size of the catalysts were determined by scanning electron microscope (SEM) equipped with electron energy dispersive X-ray spectroscopy (EDX) performed on a Leica Cambridge Stereoscan S360 operating at $15 \mathrm{kV}$. The surface area and porosity of the catalysts were examined using a Micromeritics ASAP 2000. Samples were degassed at $160{ }^{\circ} \mathrm{C}$ prior to isotherm analysis. Branauer-EmmettTeller (BET) isotherm was performed by adsorption of nitrogen at $-196{ }^{\circ} \mathrm{C}$. The surface area was then calculated using BET equation. The basicity analyses of the respective catalysts were determined by benzoic acid titration using the following indicators: bromothymol blue $\left(\mathrm{H}_{-}=7.2\right)$, phenolphthalein $\left(\mathrm{H}_{-}=8.2-9.8\right)$, 2,4-dinitroaniline $\left(\mathrm{H}_{-}=15.0\right)$ and 4-nitroaniline $\left(\mathrm{H}_{-}=18.4\right)$ [24, 25]. 


\section{Transesterification reaction}

Transesterification reaction was carried out by heating a mixture of palm cooking oil, methanol and the as-prepared catalyst in an autoclave at the desired temperature and duration. The $\mathrm{BaTiO}_{3}$ catalyst was employed to study the reaction optimization for the series of catalysts investigated. The four parameters: reaction temperatures $\left(80-180{ }^{\circ} \mathrm{C}\right)$, duration $(0.5-6.0 \mathrm{~h})$, ratios of oil to methanol $(1: 3-1: 15 \mathrm{v} / \mathrm{v})$ and catalyst loading (0.5-10.0 wt/v\% referred to the initial palm oil volume) were investigated to determine the optimum reaction conditions.

After the transesterification reaction, the mixture was allowed to cool down before separating the methyl ester (ME) by centrifugation. The products were weighed and analyzed using an Agilent 7890A gas chromatography (GC) fitted with a flame ionization detector (FID). The \% of $\mathrm{ME}$ yield was calculated using the following equation [26]:

$\%$ Methyl esters yield

$=\frac{\text { Total ME areas from GC } \times \text { weight of product }}{\text { Weight of cooking oil }} \times 100 \%$

\section{Results and discussions}

\section{Surface characterizations}

The typical morphological structures of un-doped and doped oxides are depicted in Fig. 1. All the samples show porous aggregates which were made up of distinct particles. These particles are mostly nearly spherical to cube in shape. The average particle size of the prepared $\mathrm{BaTiO}_{3}$ and $\mathrm{Ba}_{2} \mathrm{NiTi}_{5} \mathrm{O}_{13}$ are $140.0 \pm 31.0$ and $89.4 \pm 32.2 \mathrm{~nm}$, respectively. These values increased to $240.0 \pm 68.0$ and $125.1 \pm 30.5 \mathrm{~nm}$ for the respective oxides upon $\mathrm{Na}$ doping. The surface areas and pore sizes of the samples were characterized by BET analysis and are presented in Table 1. The prepared $\mathrm{BaTiO}_{3}$ and $\mathrm{Ba}_{2} \mathrm{NiTi}_{5} \mathrm{O}_{13}$ exhibited a surface area of about 3.0 and $3.8 \mathrm{~m}^{2} \mathrm{~g}^{-1}$, respectively. $\mathrm{Na}$ doping decreased the surface area (and therefore the pore size) of the oxides. For instance, the respective surface area for $\mathrm{Na}-\mathrm{BaTiO}_{3}$ and $\mathrm{Na}-\mathrm{Ba}_{2} \mathrm{NiTi}_{5} \mathrm{O}_{13}$ was 2.6 and $2.8 \mathrm{~m}^{2} \mathrm{~g}^{-1}$.

Several studies [27, 28] have shown that doping constrains the growth of oxide particles and thus smaller particles with higher surface area are obtained. However, this study shows otherwise, i.e., increment in the average particle size and a decrement in surface area and pore size upon Na doping. This may be attributed to the formation of a dense layer of $\mathrm{Na}$ secondary phase on the oxides and plugged the pores. XRD analyses (not shown) have confirmed the formation of $\mathrm{Na}_{1.7} \mathrm{Ba}_{0.45} \mathrm{Ti}_{5.85} \mathrm{O}_{13}$ and $\mathrm{NaBa}_{2 \text { - }}$ $\mathrm{NiTi}_{5} \mathrm{O}_{13}$ on the respective outermost surface of the $\mathrm{BaTiO}_{3}$ and $\mathrm{Ba}_{2} \mathrm{NiTi}_{5} \mathrm{O}_{13}[22,23]$.

As seen in Table 2, $\mathrm{BaTiO}_{3}$ and $\mathrm{Ba}_{2} \mathrm{NiTi}_{5} \mathrm{O}_{13}$ exert a total basicity of 0.540 and $0.618 \mathrm{mmol} \mathrm{g}^{-1}$, respectively. Most of the basic sites of these oxides are in the range of $7.2<\mathrm{H}_{-}<8.2$ (weaker basic sites). It covers $\sim 54 \%$ of the total basic sites. The total basicity of the oxides increased almost twofold upon $\mathrm{Na}$ doping. This was 1.062 and $1.336 \mathrm{mmol} \mathrm{g}^{-1}$ for $\mathrm{Na}-\mathrm{BaTiO}_{3}$ and $\mathrm{Na}-\mathrm{Ba}_{2}$ $\mathrm{NiTi}_{5} \mathrm{O}_{13}$, respectively. The percentage of medium basic sites in $\mathrm{Na}-\mathrm{Ba}_{2} \mathrm{NiTi}_{5} \mathrm{O}_{13}$ is higher as compared to $\mathrm{Na}$ $\mathrm{BaTiO}_{3}$. The $\mathrm{Na}_{-} \mathrm{BaTiO}_{3}$ possess $13.0 \%$ while $\mathrm{Na}-\mathrm{Ba}_{2}$ $\mathrm{NiTi}_{5} \mathrm{O}_{13}$ offers $20.4 \%$ basic sites in the range of $15.0<\mathrm{H}_{-}<18.4$.

\section{Optimization of transesterification}

The catalytic activities of $\mathrm{BaTiO}_{3}$ at various reaction parameters were compared to obtain the optimum reaction conditions. As seen in Table 3, the percentage of ME yield increases with the increase in the ratio of oil:methanol up to $1: 12(\mathrm{v} / \mathrm{v})$, and thereafter $\mathrm{ME}$ yield decreases. For instance, the ME yield for the oil:methanol ratio of 1:3 (v/ $\mathrm{v}$ ) is $82.3 \%$. This increases to 86.5 and $88.1 \%$ upon further increase in the oil:methanol volume ratio to $1: 9(\mathrm{v} / \mathrm{v})$ and $1: 12(\mathrm{v} / \mathrm{v})$ correspondingly. Further increase in the content of methanol to $1: 15(\mathrm{v} / \mathrm{v})$ caused the ME yield to drop to $78.8 \%$.

Palm oil transesterification is a reversible reaction (Eq. 2). Hence, forward reaction is favored in an excess amount of methanol, i.e., from $1: 3$ to $1: 12$ (v/v) oil:methanol. However, at high methanol ratio (in the 1:15 (v/ v) oil to methanol), the dilution effect becomes prominent. This caused a reduction in reaction rate, hence a lower ME yield is obtained [29]. In addition, large amount of methanol can also promote the solubility of glycerol in the oil and can cause difficulty in the separation of glycerol [30]. Therefore, the ratio of oil to methanol of $1: 12(\mathrm{v} / \mathrm{v})$ is chosen for this transesterification study.

Triglycerides + methanol $\leftrightarrow$ methyl ester + glycerol.

The catalyst loading is another factor that affects the ME yield. Typically, increasing the loading amount of catalysts may provide more catalytic sites for reactants to dock on. In this study, it is observed that the \% of ME yield increases gradually from 0.5 to $10 \mathrm{wt} / \mathrm{v} \%$ catalyst loading. The ME yield was $78.2,84.5,88.1$ and $88.8 \%$ for the 0.5 , 2.0, 5.0 and $10.0 \mathrm{wt} / \mathrm{v} \% \mathrm{BaTiO}_{3}$ loading, respectively. The 
Fig. 1 Typical SEM micrographs of a $\mathrm{BaTiO}_{3}$, b Na$\mathrm{BaTiO}_{3}, \mathbf{c} \mathrm{Ba}_{2} \mathrm{NiTi}_{5} \mathrm{O}_{13}$ and d $\mathrm{Na}-\mathrm{Ba}_{2} \mathrm{NiTi}_{5} \mathrm{O}_{13}$
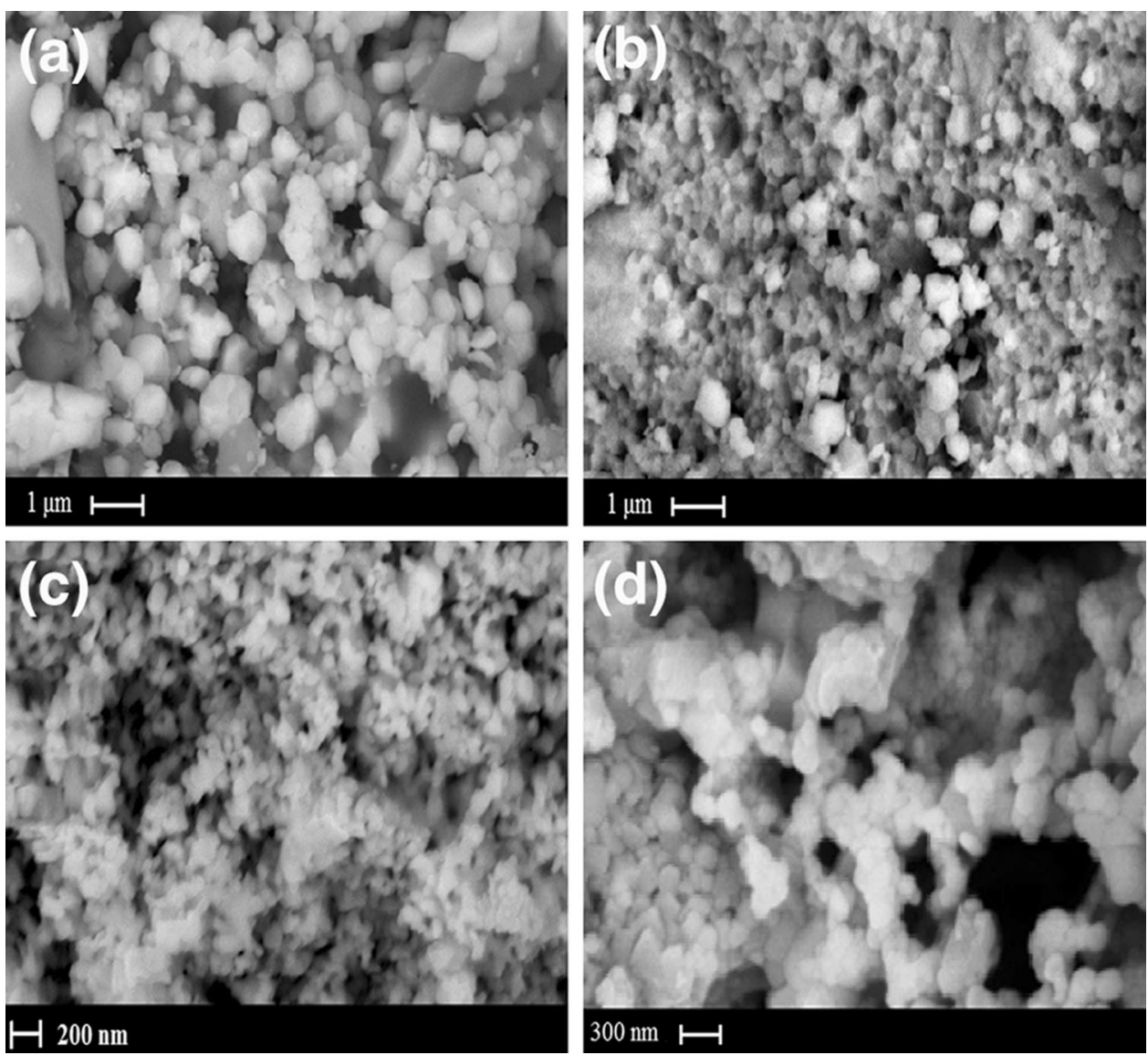

Table 1 Surface characteristics of various barium-containing catalysts

\begin{tabular}{lllc}
\hline Catalyst & $\begin{array}{l}\text { Surface area } \\
\left(\mathrm{m}^{2} \mathrm{~g}^{-1}\right)\end{array}$ & $\begin{array}{l}\text { Pore size } \\
(\mathrm{nm})\end{array}$ & Particle size (nm) \\
\hline $\mathrm{BaTiO}_{3}$ & 3.0 & 30.5 & $140.0 \pm 31.0$ \\
$\mathrm{Na}^{-\mathrm{BaTiO}_{3}}$ & 2.6 & 21.7 & $240.0 \pm 68.0$ \\
$\mathrm{Ba}_{2} \mathrm{NiTi}_{5} \mathrm{O}_{13}$ & 3.8 & 39.5 & $89.4 \pm 32.2$ \\
$\mathrm{Na}_{-}-\mathrm{Ba}_{2} \mathrm{NiTi}_{5} \mathrm{O}_{13}$ & 2.8 & 30.8 & $125.1 \pm 30.5$ \\
\hline
\end{tabular}

Table 2 Basicity of various oxides and their $\mathrm{Na}$-doped counterparts

\begin{tabular}{llllll}
\hline Catalyst & \multicolumn{2}{l}{ Basicity $\left(\mathrm{mmol} \mathrm{g}^{-1}\right)$} & $\begin{array}{c}\text { Total basicity } \\
\left(\mathrm{mmol} \mathrm{g}^{-1}\right)\end{array}$ \\
\cline { 2 - 5 } & $\mathrm{H}_{-}=7.2$ & $\mathrm{H}_{-}=8.2-9.8$ & $\mathrm{H}_{-}=15.0$ & $\mathrm{H}_{-}=18.4$ & \\
\hline $\mathrm{BaTiO}_{3}$ & 0.29 & 0.15 & 0.10 & 0 & 0.540 \\
$\mathrm{Na}_{-} \mathrm{BaTiO}_{3}$ & 0.74 & 0.19 & 0.14 & 0 & 1.062 \\
$\mathrm{Ba}_{2} \mathrm{NiTi}_{5} \mathrm{O}_{13}$ & 0.33 & 0.17 & 0.12 & 0 & 0.618 \\
$\mathrm{Na}_{-} \mathrm{Ba}_{2} \mathrm{NiTi}_{5} \mathrm{O}_{13}$ & 0.90 & 0.16 & 0.27 & 0 & 1.336 \\
\hline
\end{tabular}

$\%$ yield for the 5 and $10 \mathrm{wt} / \mathrm{v} \%$ catalyst is similar. Accordingly, the $5 \mathrm{wt} / \mathrm{v} \%$ catalyst was chosen as the optimum amount for further studies.

An increment of ME yield from 76.0 to $88.1 \%$ is achieved via increasing the reaction temperature from 80 to $150{ }^{\circ} \mathrm{C}$. Beyond $150{ }^{\circ} \mathrm{C}$, the ME yield is constant. Generally, increasing temperature helps in homogenizing the reactants, making them more readily to react [31]. Hence, this may assist the transesterification to reach equilibrium faster, and thus affects the $\%$ of $\mathrm{ME}$ yield for transesterification.

As shown in Table 3, the \% of ME yield increases from 74.8 to $88.1 \%$ when increasing the time duration from 0.5 to $2 \mathrm{~h}$. After that, the reaction yield is more or less constant ( $\sim 90-92 \%$ ). Hence, it is envisaged that $2 \mathrm{~h}$ is sufficient to complete the reaction. 
Table 3 Methyl ester conversion of the $\mathrm{BaTiO}_{3}$ catalyst at various conditions

\begin{tabular}{lllll}
\hline Parameters & & & & $\begin{array}{l}\text { ME } \\
\text { yield }\end{array}$ \\
\hline $\begin{array}{l}\text { Ratio of oil: } \mathrm{CH}_{3} \mathrm{OH} \\
(\mathrm{v} / \mathrm{v})\end{array}$ & $\begin{array}{l}\text { Temperature } \\
(\mathrm{C})\end{array}$ & $\begin{array}{l}\text { Duration } \\
(\mathrm{h})\end{array}$ & $\begin{array}{l}\text { Catalyst loading } \\
(\mathrm{wt} / \mathrm{v} \%)\end{array}$ & 82.3 \\
\hline $1: 3$ & 150 & 2.0 & 5.0 & 86.4 \\
$1: 6$ & 150 & 2.0 & 5.0 & 86.5 \\
$1: 9$ & 150 & 2.0 & 5.0 & 88.1 \\
$1: 12$ & 150 & 2.0 & 5.0 & 78.8 \\
$1: 15$ & 150 & 2.0 & 5.0 & 78.2 \\
$1: 12$ & 150 & 2.0 & 0.5 & 84.4 \\
$1: 12$ & 150 & 2.0 & 1.0 & 84.5 \\
$1: 12$ & 150 & 2.0 & 2.0 & 88.8 \\
$1: 12$ & 150 & 2.0 & 10.0 & 74.8 \\
$1: 12$ & 150 & 0.5 & 5.0 & 79.5 \\
$1: 12$ & 150 & 1.0 & 5.0 & 90.8 \\
$1: 12$ & 150 & 3.0 & 5.0 & 91.3 \\
$1: 12$ & 150 & 4.0 & 5.0 & 92.0 \\
$1: 12$ & 150 & 5.0 & 5.0 & 92.1 \\
$1: 12$ & 150 & 6.0 & 5.0 & 76.0 \\
$1: 12$ & 80 & 2.0 & 5.0 & 80.8 \\
$1: 12$ & 100 & 2.0 & 5.0 & 82.3 \\
$1: 12$ & 120 & 2.0 & 5.0 & 88.2 \\
$1: 12$ & 180 & 2.0 & 5.0 &
\end{tabular}

\section{Transesterification of palm cooking oil}

As shown in Table 2, $\mathrm{BaTiO}_{3}$ demonstrated $88 \%$ of $\mathrm{ME}$ yield. $\mathrm{Ba}_{2} \mathrm{NiTi}_{5} \mathrm{O}_{13}$ gave a higher $\mathrm{ME}$ value of $91 \%$ as compared to $\mathrm{BaTiO}_{3}$. These values increased 2-6\% upon doping $0.5 \mathrm{wt} \% \mathrm{Na}$ into the respective oxide catalysts. The catalytic activity of barium-containing catalysts follows the trend of decreasing order of $\mathrm{Na}-\mathrm{Ba}_{2} \mathrm{NiTi}_{5} \mathrm{O}_{13}>\mathrm{Ba}_{2}$ $\mathrm{NiTi}_{5} \mathrm{O}_{13}>\mathrm{Na}-\mathrm{BaTiO}_{3}>\mathrm{BaTiO}_{3}$.

In general, the catalytic properties are influenced by particle size, surface area, as well as the active sites of a catalyst. Small sized catalyst with high surface area and active sites will give rise to high catalytic performance. In this study, however, the sizes and surface areas seem to contribute to only minor extent towards transesterification. Instead, the catalytic performance of the series of un-doped and doped barium-containing titanate catalysts is believed to be closely related to their basic sites. For instance, the $\mathrm{Na}-\mathrm{Ba}_{2} \mathrm{NiTi}_{5} \mathrm{O}_{13}$ which the highest amount of medium basic sites displayed the highest catalytic activity. However, the $\mathrm{Na}-\mathrm{BaTiO}_{3}$ with the smallest average particle size gave lower catalytic activity even though it offers the highest surface area among the series. A similar finding was reported by Nascimento et al. [32]. As previously mentioned [22, 23], a dense layer of $\mathrm{Na}$ secondary phase was formed onto the surface of barium-containing titanate catalysts in the Na-doped system. There are 50\% more basic sites located on these $\mathrm{Na}$ secondary phase as compared to un-doped system. These sites are actively involved in the adsorption of methanol in which the $\mathrm{O}-\mathrm{H}$ bonds of the methanol readily break into methoxides and proton [33]. The methoxides formed then reacted with the triglyceride to yield methyl esters and glycerols. The proposed mechanism is depicted in Fig. 2.

Table 4 also shows a comparison of catalytic activity between this work and other barium-containing catalyst systems. As can be seen, the ME yield (88-95\%) obtained in this work are comparable to the previous reported values. The highest ME yield achieved in the literature was $100 \%$ for the $\mathrm{Ba}_{0.04} \mathrm{La}_{1.96} \mathrm{O}_{3}$ catalyst using rapeseed oil as the feed stock. Nevertheless, higher catalyst loading and temperature, as well as a longer reaction time were needed as compared to this study.

\section{Conclusion}

$\mathrm{BaTiO}_{3}, \mathrm{Ba}_{2} \mathrm{NiTi}_{5} \mathrm{O}_{13}$ and their Na-doped analogues were successfully synthesized via sol-gel and calcination method. The prepared $\mathrm{BaTiO}_{3}$ and $\mathrm{Ba}_{2} \mathrm{NiTi}_{5} \mathrm{O}_{13}$ exert porous aggregated structure with specific surface area of $3-4 \mathrm{~m}^{2} \mathrm{~g}^{-1}$. They displayed a total basicity of $0.5-0.6 \mathrm{mmol} \mathrm{g}{ }^{-1}$ with $\sim 81 \%$ of weak basic sites. Doping these oxides with $\mathrm{Na}$ increased their total basicity (i.e., to 1.1-1.3 $\mathrm{mmol} \mathrm{g}^{-1}$ ) but decreased their surface area and pore size. This may be attributed to the formation of a dense 


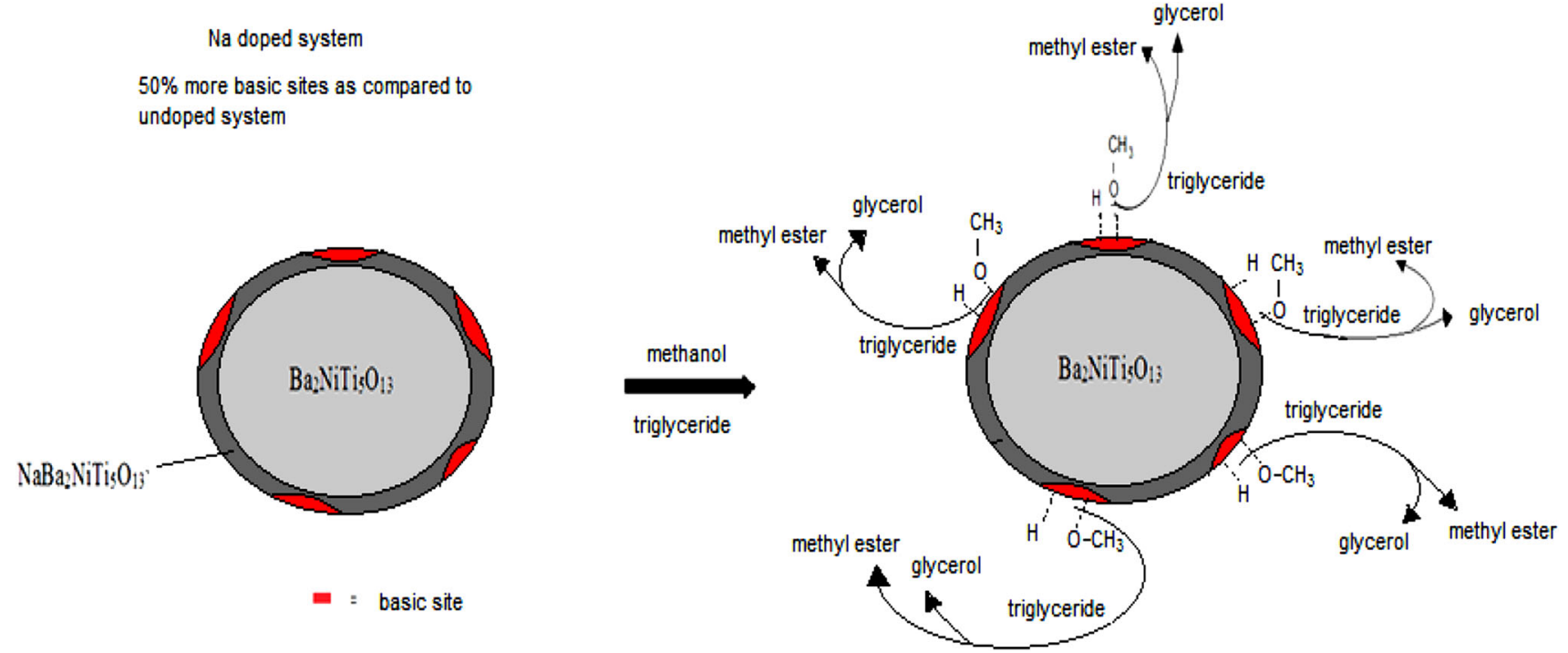

Fig. 2 Proposed mechanism for the beneficial effect of adding $\mathrm{Na}$ onto the barium-containing titanate catalysts

Table 4 Comparison of catalytic performance of various barium-containing catalysts in the literature

\begin{tabular}{|c|c|c|c|c|c|c|c|}
\hline \multirow[t]{2}{*}{ Catalyst } & \multirow[t]{2}{*}{ Type of oil } & \multicolumn{4}{|c|}{ Reaction condition } & \multirow[t]{2}{*}{$\operatorname{ME}(\%)$} & \multirow[t]{2}{*}{ Ref. } \\
\hline & & $\begin{array}{l}\text { Loading } \\
\text { (wt } \%)\end{array}$ & $\begin{array}{l}\text { Methanol:oil } \\
\text { ratio(v/v) }\end{array}$ & $\begin{array}{l}\text { Temperature } \\
\left({ }^{\circ} \mathrm{C}\right)\end{array}$ & $\begin{array}{l}\text { Duration } \\
\text { (min) }\end{array}$ & & \\
\hline $\mathrm{BaZrO}_{3}$ & Keranja & 1 & $27: 1$ & 65 & 180 & 99 & {$[34]$} \\
\hline Ba-MMT & Waste cooking & 3.5 & $12: 1$ & 150 & 300 & 83 & [7] \\
\hline $\mathrm{Ba}(\mathrm{OH})_{2}$ & Corn & 3.6 & 11.32:1 & 33 & 118 & 99 & {$[35]$} \\
\hline Ba-Sr/ZSM-5 & Sunflower & 3 & $9: 1$ & 60 & 180 & 88 & {$[36]$} \\
\hline $\mathrm{Ba}_{0.04} \mathrm{La}_{1.96} \mathrm{O}_{3}$ & Rapeseed & 6 & $9: 1$ & 200 & 540 & 100 & {$[20]$} \\
\hline $\mathrm{BaAl}_{12} \mathrm{O}_{19}$ & Rapeseed & 2 & $9: 1$ & 200 & 540 & 60 & {$[20]$} \\
\hline $\mathrm{Na}-\mathrm{Ba}_{2} \mathrm{NiTi}_{5} \mathrm{O}_{13}$ & Palm & 5 & $15: 1$ & 150 & 120 & 95 & This study \\
\hline $\mathrm{Ba}_{2} \mathrm{NiTi}_{5} \mathrm{O}_{13}$ & Palm & 5 & $15: 1$ & 150 & 120 & 91 & This study \\
\hline $\mathrm{Na}-\mathrm{BaTiO}_{3}$ & Palm & 5 & $15: 1$ & 150 & 120 & 90 & This study \\
\hline $\mathrm{BaTiO}_{3}$ & Palm & 5 & $15: 1$ & 150 & 120 & 88 & This study \\
\hline
\end{tabular}

layer of Na secondary phase on the oxides that plugged the pores. The optimum conditions for the transesterification were obtained with $5 \mathrm{wt} / \mathrm{v} \%$ catalysts loading at oil to methanol ratio of $1: 12(\mathrm{v} / \mathrm{v})$ and at $150{ }^{\circ} \mathrm{C}$ for $2 \mathrm{~h}$. Both undoped and doped $\mathrm{BaTiO}_{3}$ and $\mathrm{Ba}_{2} \mathrm{NiTi}_{5} \mathrm{O}_{13}$ showed good catalytic activity towards the transesterification of palm cooking oil with more than $85 \%$ conversion. The catalytic activity of barium-containing titanate catalysts follows the trend of decreasing order of $\mathrm{Na}-\mathrm{Ba}_{2} \mathrm{NiTi}_{5} \mathrm{O}_{13}>\mathrm{Ba}_{2} \mathrm{NiTi}_{5-}$ $\mathrm{O}_{13}>\mathrm{Na}_{-} \mathrm{BaTiO}_{3}>\mathrm{BaTiO}_{3}$. The catalytic performance of these series of un-doped and doped barium-containing catalysts is believed to be closely related to their surface basic sites but not the total surface area.

Acknowledgements The authors wish to thank the Universiti Sains Malaysia for the financial support in the form of Grant: RU 1001/PKIMIA/811311.
Open Access This article is distributed under the terms of the Creative Commons Attribution 4.0 International License (http://crea tivecommons.org/licenses/by/4.0/), which permits unrestricted use, distribution, and reproduction in any medium, provided you give appropriate credit to the original author(s) and the source, provide a link to the Creative Commons license, and indicate if changes were made.

\section{References}

1. Sajjada, B., Abdul Rahman, A.A., Arandiyah, H.: A comprehensive review on properties of edible and non-edible vegetable oil-based biodiesel: composition, specifications and prediction models. Renew Sust Energy Rev 63, 62-92 (2016)

2. Demirbas, A.: Biodiesel: a realistic fuel alternative for diesel engines. Springer, London (2007)

3. Leung, D.Y.C., Wu, X., Leung, M.K.H.: A review on biodiesel production using catalyzed transesterification. Appl Energy 87, 1083-1095 (2010) 
4. Avhad, M.R., Marchetti, J.M.: Innovation in solid heterogeneous catalysis for the generation of economically viable and ecofriendly biodiesel: a review. Catal Rev Sci Eng 58, 157-208 (2016)

5. Chorkendoff, I., Niemantsverdriet, J.W.: Concepts of modern catalysis and kinetic. Wiley, Weiheim (2003)

6. Mar, W., Samsook, E.: Methanolysis of soybean oil over $\mathrm{KCl} /$ $\mathrm{CaO}$ solid base catalyst for biodiesel production. Sci Asia 38, 90-94 (2012)

7. Olutoye, M.A., Wong, S.W., Chin, L.H., Amani, H., Asif, M., Hameed, B.H.: Synthesis of fatty acid methyl esters via the transesterification of waste cooking oil by methanol with a barium-modified montmorillonite K10 catalyst. Renew Energy 86, 392-398 (2016)

8. Mukenga, M., Muzenda, E., Jalama, K., Mijiboom, R.: Biodiesel production from soybean oil over $\mathrm{TiO}_{2}$ supported nano-ZnO. Int J Chem Nucl Mater Metall Eng 6, 348-352 (2012)

9. Lee, H.V., Taufiq-Yap, Y.H., Hussein, M.Z., Yunus, R.: Transesterification of jatropha oil with methanol over $\mathrm{Mg}-\mathrm{Zn}$ mixed metal oxide catalysts. Energy 49, 12-18 (2013)

10. Fan, M., Liu, Y., Zhang, P., Jiang, P.: Blocky shapes Ca-Mg mixed oxides as a water-resistant catalyst for effective synthesis of biodiesel by transesterification. Fuel Process Technol 149, 163-168 (2016)

11. Gotcht, A.J., Reeder, A.J., McCormick, A.: Study of heterogeneous base catalysts for biodiesel production. J Undergrad Chem Res 8, 22-26 (2009)

12. Patil, P., Gude, V.G., Pinappu, S., Deng, S.: Transesterification kinetics of Camelina sativa oil on metal oxide catalysts under conventional and microwave heating conditions. Chem Eng J 168, 1296-1300 (2011)

13. Babak, S., Iman, H., Abdullah, A.Z.: Alkaline earth metal oxide catalysts for biodiesel production from palm oil: elucidation of process behaviors and modeling using response surface methodology. Iran J Chem Chem Eng 32, 113-126 (2013)

14. Mootabadi, H., Salamatinia, B., Bhatia, S., Abdullah, A.Z.: Ultrasonic-assisted biodiesel production process from palm oil using alkaline earth metal oxides as the heterogeneous catalysts. Fuel 89, 1818-1825 (2010)

15. Patil, P.D., Gude, V.G., Deng, S.: Biodiesel production from Jatropha Curacas, waste cooking and Camelina Sativa Oils. Ind Eng Chem Res 48, 10850-10856 (2009)

16. Martinez-Guerra, E., Gude, V.G.: Transesterification of used vegetable oil catalyzed by barium oxide under simultaneous microwave and ultrasound irradiations. Energy Convers Manag 88, 633-640 (2014)

17. Anderson, J.A., Beaton, A., Galadima, A., Wells, R.P.K.: Role of Baria dispersion in $\mathrm{BaO} / \mathrm{Al}_{2} \mathrm{O}_{3}$ catalysts for transesterification. Catal Lett 131, 213-218 (2009)

18. Sullivan, J.A., Sherry, L.: Different dispersions of group II catalysts over SBA-15 and MCM-41: effects on transesterification reactivity. Catal Comm 60, 88-91 (2015)

19. Mierczynski, P., Ciesielski, R., Kedziora, A., Maniukiewicz, W., Shtyka, O., Kubicki, J., Albinska, J., Maniecki, T.P.: Biodiesel production on $\mathrm{MgO}, \mathrm{CaO}, \mathrm{SrO}$ and $\mathrm{BaO}$ oxides supported on (SrO) $\left(\mathrm{Al}_{2} \mathrm{O}_{3}\right)$ mixed oxide. Catal Lett 145, 1196-1205 (2015)

20. Sherstyuk, O.V., Ivanova, A.S., Lebedev, M.Y., Bukhtiyarova, M.V., Matvienko, L.G., Budneva, A.A., Simonov, A.N., Yakovlev, V.A.: Transesterification of rapeseed oil under flow conditions catalyzed by basic solids: $\mathrm{M}-\mathrm{Al}(\mathrm{La})-\mathrm{O}(\mathrm{M}=\mathrm{Sr}, \mathrm{Ba})$, $\mathrm{M}-\mathrm{Mg}-\mathrm{O}(\mathrm{M}=\mathrm{Y}$, La). Appl Catal A Gener 419-420, 73-83 (2012)

21. Ivanova, A.S., Sherstyuk, O.V., Bukhtiyarova, M.V., Kukushkin, R.G., Matvienko, L.G., Plyasova, L.M., Kaichev, V.V., Simonov, A.N., Yakovlev, V.A.: Performance of Ba-containing catalysts in the transesterification reaction of rapeseed oil with methanol under flow conditions. Catal Comm 18, 156-160 (2012)

22. Chew, K.Y., Abu Bakar, M., Abu Bakar, N.H.H.: Effects of sodium doping on phase composition and morphology of barium titanate particles. AIP Conf Proc 1502, 348-367 (2012)

23. Chew, K.Y., Abu Bakar, M.: Two steps synthesis of quaternary metal titanate of $\mathrm{Ba}_{2} \mathrm{NiTi}_{5} \mathrm{O}_{13}$ and characterization. Adv Mater Res 364, 353-358 (2012)

24. Markowitz, M.A., Schoen, P.E., Kust, P., Gaber, B.P.: Surface acidity and basicity of functionalized silica particles. Colloids Surf A 150, 85-94 (1999)

25. Van Laar, F.M.P.R., De Vos, D.E., Pierard, F., Kirsch-De Mesmaeker, A., Fiermans, L., Jacobs, P.A.: Generation of singlet molecular oxygen from $\mathrm{H}_{2} \mathrm{O}_{2}$ with molybdate-exchanged layered double hydroxides: effects of catalyst composition and reaction conditions. J Catal 197, 139-150 (2001)

26. Omar, Wan: W.N.N., Amin, N.A.S.: Biodiesel production from waste cooking oil over alkaline modified zirconia catalyst. Fuel Process. Technol. 92, 2397-2405 (2011)

27. Hinojosa-Reyes, M., Arriaga, S., Diaz-Torres, L.A., RodríguezGonzález, V.: Gas-phase photocatalytic decomposition of ethylbenzene over perlite granules coated with indium doped $\mathrm{TiO}_{2}$. Chem Eng J 224, 106-113 (2013)

28. Li, Y., Li, J., Li, Q., Yu, G.-L., Zhang, H.-W.: Structure and magnetic properties of NiCuZn ferrite materials with La doping. Rare Met (2013). doi:10.1007/s12598-014-0376-2

29. Gao, L., Xu, B., Xiao, G., Lu, J.: Transesterification of palm oil with methanol to biodiesel over a $\mathrm{KF} / \mathrm{hydrotalcite}$ solid catalyst. Energy Fuels 22, 3531-3535 (2008)

30. Meher, L.C., Kulkarni, M.G., Dalai, A.K., Naik, S.N.: Transesterification of karanja (Pongamia pinnata) oil by solid basic catalysts. Eur J Lipid Sci Technol 108, 389-397 (2006)

31. Nguyen, T., Do, L., Sabatini, D.A.: Biodiesel production via peanut oil extraction using diesel-based reverse-micellar microemulsions. Fuel 89, 2285-2291 (2010)

32. Nascimento, G.S., Mambrini, G.P., Paris, E.C., Peres, J.A., Colnago, L.A., Ribeiro, C.: Evaluation of the catalytic activity of oxide nanoparticles synthesized by the polymeric precursor method on biodiesel production. J Mater Res 27, 3020-3026 (2012)

33. Refaat, A.A.: Biodiesel production using solid metal oxide catalysts. Int J Environ Sci Technol 8, 203-221 (2011)

34. Singh, V., Hameed, B.H., Sharma, Y.C.: Economically viable production of biodiesel from a rural feedstock from eastern India, $P$. pinnata oil using a recyclable laboratory synthesized heterogeneous catalyst. Energy Convers Manag 122, 52-62 (2016)

35. Mustafa, F., Bicu, I.: The optimization of the production of methyl esters from corn oil using barium hydroxide as a heterogeneous catalyst. J Am Oil Chem Soc 91, 839-847 (2014)

36. Feyzi, M., Khajavi, G.: Investigation of biodiesel production using modified strontium nanocatalysts supported on the ZSM-5 zeolite. Ind Crops Prod 58, 298-304 (2014) 